\title{
ADVERSE EFFECTS: CAN THE FAIR WORK ACT ADDRESS WORKPLACE DISCRIMINATION FOR EMPLOYEES WITH A DISABILITY?
}

\author{
DOMINIQUE ALLEN*
}

The enactment of the Fair Work Act 2009 (Cth) ('FWA') gave employees a new mechanism for addressing workplace discrimination in addition to traditional anti-discrimination law. Section 351 of the FWA prohibits employers from taking adverse action against employees on a range of grounds including disability. This article evaluates whether section 351 can effectively address disability discrimination in the workplace. It argues that section 351 offers limited protection to employees with a disability because the FWA does not define 'disability', and the courts have interpreted 'discrimination' too narrowly to encompass the complexities of workplace discrimination. However, the FWA contains stronger enforcement mechanisms than anti-discrimination law so, with some refinements, it could offer employees with a disability a much more effective avenue for addressing discrimination than traditional antidiscrimination laws.

\section{INTRODUCTION}

Data recently published by the Australian Human Rights Commission ('AHRC') showed that the workforce participation rate for people with a disability in Australia is low, particularly compared to other Organisation for Economic Co-operation and Development ('OECD') countries, and it has been low for the last 20 years. ${ }^{1}$ The AHRC reported that the labour force participation

* Senior Lecturer, Department of Business Law and Taxation, Monash University. I would like to thank Belinda Smith and Neil Rees for their thoughts on an earlier version of this article, and the referees for their helpful feedback. I wrote a substantial part of this article during a departmental writing retreat. I am very grateful to Michelle Welsh and Nicola Charwat at Monash University, and to my family for the opportunity to attend that retreat.

1 Australian Human Rights Commission, 'Willing to Work: National Inquiry into Employment Discrimination against Older Australians and Australians with Disability' (Report, 2016) 6 ('Willing to Work'). Of the 29 OECD countries, Australia, at 40 per cent, ranks 21 in terms of employment rates for people with a disability. Overall, though, the employment rates in these countries are not high. Fifteen countries are grouped between 40 per cent and 50 per cent. The country with the highest rank is Sweden, at 62 per cent: Organisation for Economic Co-operation and Development, 'Sickness, Disability and Work: Breaking the Barriers - A Synthesis of Findings across OECD Countries' (Report, 2010) fig 2.1. 
rate for people with a disability is 53.4 per cent compared to 83.2 per cent for people without a disability. ${ }^{2}$ Some of the barriers faced by people with a disability in accessing employment that the AHRC identified included: inaccessible recruitment practices, a lack of understanding in the workplace about the nature of the disability or how it could be accommodated, inaccessible workplaces due to the design of the building or the nature of the technologies used, and employers who are unwilling to make adjustments to accommodate a disability. ${ }^{3}$

Discrimination in employment on the basis of a person's disability has been prohibited federally since the enactment of the Disability Discrimination Act 1992 (Cth) ('DDA'). New South Wales and South Australia were the first to prohibit disability discrimination in 1981. The rest of the states and territories followed suit, the last being Tasmania in 1998. Yet discrimination persists for people with a disability. By far, the largest category of complaints that the AHRC and its state and territory equivalents receive are about disability discrimination. ${ }^{4}$ In 2016-17 the AHRC received 755 complaints about disability discrimination compared to 465 about sex discrimination, 409 about race discrimination and 154 about age discrimination. ${ }^{5}$ Of the complaints the Commission received about disability discrimination, 33 per cent were about employment. ${ }^{6}$

The criticisms of disability discrimination laws (like anti-discrimination laws more generally) include that they contain complex definitions of discrimination, most claims settle or are withdrawn so there is very little case law, the burden of proof rests on the individual employee, there is no scope for agency enforcement, and, for those who are successful, courts predominantly award individualised remedies (primarily compensation), which do not address systemic issues such as providing access to a building or a service. ${ }^{7}$

See also the specific country reports: Organisation for Economic Co-operation and Development, Country-Specifics Findings (2018) < http://www.oecd.org/publications/sickness-disability-and-workbreaking-the-barriers-9789264088856-en.htm>.

2 Australian Human Rights Commission, Willing to Work, above n 1, 41. See also app 2.

3 Ibid ch 4.

4 A table of the number of discrimination complaints lodged on the basis of disability in each jurisdiction across all areas in which discrimination is prohibited is available in Neil Rees, Simon Rice and Dominique Allen, Australian Anti-Discrimination and Equal Opportunity Law (Federation Press, 2018) 421.

5 Australian Human Rights Commission, ‘2016-2017 Complaint Statistics’ (2017) 7 table 9. However, in Willing to Work, the AHRC stated that complaints are only one indicator of the prevalence of discrimination and it has found that discrimination is under-reported. The submissions the inquiry received reflected this: Willing to Work, above $\mathrm{n} 1,320 \mathrm{ff}$.

6 Australian Human Rights Commission, '2016-2017 Complaint Statistics', above n 5, 22-3 table 27.

7 See generally Beth Gaze, 'Context and Interpretation in Anti-Discrimination Law' (2002) 26 Melbourne University Law Review 325; Jonathon Hunyor, 'Skin-Deep: Proof and Inferences of Racial Discrimination in Employment' (2003) 25 Sydney Law Review 535; Jacob Campbell, 'Using AntiDiscrimination Law as a Tool of Exclusion: A Critical Analysis of the Disability Discrimination Act 1992 and Purvis v NSW' (2005) 5 Macquarie Law Journal 201; Belinda Smith, 'Not the Baby and the Bathwater: Regulatory Reform for Equality Laws to Address Work-Family Conflict' (2006) 28 Sydney Law Review 689; Dominique Allen, 'Strategic Enforcement of Anti-Discrimination Law: A New Role for Australia’s Equality Commissions’ (2010) 36 Monash University Law Review 103. 
It is in this context that a new provision prohibiting discrimination in the workplace contained in the Fair Work Act 2009 (Cth) ('FWA' or 'the Act') ${ }^{8}$ was received with optimism. Section 351 of the $F W A$ is titled 'Discrimination' and it provides: '(1) An employer must not take adverse action against a person who is an employee, or prospective employee, of the employer because of the person's ... physical or mental disability'. Smith wrote:

by avoiding the prescriptive drafting of anti-discrimination laws these new rights [in section 351] are not automatically subject to the limitations of antidiscrimination jurisprudence. Importantly, this open drafting provides the courts (and parties) with an opportunity to develop modern and more workable antidiscrimination principles.

Harpur, French and Bales described section 351 and its enforcement as 'a transformational development in the struggle to achieve workplace equality'. ${ }^{10}$ Rice and Roles were more cautious, stating that section 351 offers 'exciting possibilities and significant causes for reservation'. ${ }^{11}$ They saw the simplified language of the provision compared to complex anti-discrimination laws as a positive, but one of their reasons for being reserved was that the FWA did not define the term 'discriminate'. ${ }^{12}$ They wrote that section 351's usefulness is 'compromised by failure to take account of the lessons learned in antidiscrimination law as to how best to anticipate the circumstances in which employees can be discriminated against' ${ }^{13}$

The purpose of this article is to evaluate whether section 351 of the $F W A$ can effectively address disability discrimination in the workplace. It argues that section 351 offers a limited protection to employees with a disability because the Act does not define 'disability', and the courts have interpreted 'discrimination' too narrowly to encompass the complexities of workplace discrimination. However, the FWA contains stronger enforcement mechanisms than antidiscrimination law so, with some refinements, it could offer employees with a disability a much more effective avenue for addressing discrimination than traditional anti-discrimination laws.

Section 351 contains three elements: first, the employee or prospective employee must have a physical or mental disability; second, the employer must engage in adverse action; and third, the adverse action must be taken because of the disability. From the outset, it is worth highlighting that section 351 does not use the words 'discriminate' or 'discrimination', apart from the heading which

Prior to the commencement of the $F W A$, employers were only prohibited from terminating an employee because of an attribute they possessed, such as their race, age or disability. The FWA extended this prohibition to include a group of behaviours known as 'adverse action'.

9 Belinda Smith, 'Fair and Equal in the World of Work: Two Significant Federal Developments in Australian Discrimination Law' (2010) 23 Australian Journal of Labour Law 199, 212.

10 Paul Harpur, Ben French and Richard Bales, 'Australia's Fair Work Act and the Transformation of Workplace Disability Discrimination Law' (2012) 30 Wisconsin International Law Journal 190, 193.

11 Simon Rice and Cameron Roles, “'It's a Discrimination Law Julia, but Not As We Know It": Part 3-1 of the Fair Work Act' (2010) 21(1) Economic and Labour Relations Review 13, 14.

12 Ibid.

13 Ibid 15. 
does not form part of the Act for the purposes of interpretation. ${ }^{14}$ By contrast, anti-discrimination laws define discrimination. ${ }^{15}$ Rice and Roles wrote that describing section 351 as a 'discrimination' provision is misleading and it would be better described as 'attribute-based protection'. ${ }^{16}$ This article begins by unpacking two of the elements in the prohibition itself. Part II considers 'physical or mental disability' and Part III examines 'discrimination' as a form of adverse action. Essentially, Parts II and III reveal a significant problem - the courts are interpreting 'physical or mental disability' and 'discrimination' very narrowly. Consequently, the FWA cannot effectively address disability discrimination. Unlike anti-discrimination laws, the $F W A$ contains strong enforcement mechanisms, namely, a shifting onus of proof, civil penalties, and independent regulator which can enforce the law. They are considered in Part III. Part IV offers some suggestions for improving the $F W A$ so that it could more effectively address disability discrimination in the workplace. At times, it is necessary to compare the $F W A$ to examples of anti-discrimination law. For simplicity, the $D D A$ is used as the comparator. ${ }^{17}$

\section{THE MEANING OF PHYSICAL OR MENTAL DISABILITY}

Section 351 prohibits employers from taking adverse action against potential and actual employees on a range of attributes they possess including their physical and mental disability. The behaviour - the adverse action - is defined in section 342 and includes 'to discriminate'. It is considered in Part III. This Part considers how the federal courts have interpreted the meaning of physical and mental disability to date. Physical and mental disability, like the 12 other attributes listed in section 351, is not defined in the Act. It is not clear why the drafters chose not to define disability (or indeed any of the attributes in section 351 ) or why they did not import the broad definition in section 4 of the $D D A \cdot{ }^{18}$ In many cases this has not been problematic as the court has accepted that the employee's condition constituted a disability but in the instances in which it has had to determine what disability means, its approach has been far more restrictive than under the $D D A$.

14 Acts Interpretation Act 1901 (Cth) s 13(3). This provision formerly excluded headings from forming part of an Act, but was amended in 2011 to state that headings do form part of the Act. Section 40A was subsequently inserted into the FWA which states that '(1) The Acts Interpretation Act 1901, as in force on 25 June 2009, applies to this Act'. Consequently, the headings do not form part of the $F W A$ for the purposes of interpretation.

15 See, eg, $D D A$ ss 5-6.

16 Rice and Roles, above n 11, 14.

17 It operates in much the same way as the eight state and territory anti-discrimination Acts which also prohibit disability discrimination. For a detailed analysis of disability discrimination laws, see Rees, Rice and Allen, above $\mathrm{n}$ 4, ch 7.

18 Neither the Explanatory Memorandum to the Fair Work Bill 2009 (Cth) or the Second Reading Speech shed any light on this or clarify how the attributes should be interpreted: see Explanatory Memorandum, Fair Work Bill 2008 (Cth); Commonwealth, Parliamentary Debates, House of Representatives, 25 November 2008, 11189 (Julia Gillard). 


\section{A The Ordinary Meaning of Disability}

The only other references to 'disability' contained in the FWA relate to the Fair Work Commission's role setting the national minimum wage. The Commission can set special wages for employees with a disability ${ }^{19}$ and the Act states that terms about different wages for employees with a disability in an industrial agreement will not be discriminatory. ${ }^{20}$ Section 12 defines an 'employee with a disability' as a national system employee ${ }^{21}$ who is qualified to receive a disability support pension under the Social Security Act 1991 (Cth). The narrowest interpretation of disability for the purposes of section 351 resulted from incorrectly using this definition. In Construction, Forestry, Mining and Electrical Union v Leighton Contractors Pty Ltd, ${ }^{22}$ and Corke-Cox v Crocker Builders Pty Ltd $^{23}$ Burnett FM found that the employee in question had only a minor injury that they had incurred in the workplace so they did not qualify for a disability support pension. Consequently, both employees' claims failed.

When interpreting the meaning of 'disability', courts have relied heavily on the principle of statutory interpretation that undefined terms are to be given their ordinary meaning. In most of the disability discrimination cases, the court has simply accepted that the condition in question was a disability. In Silver $v$ Rogers, Burnett FM said that there was 'no issue' that the complainant's 'health related issues' (a golden staph infection contracted following a triple bypass operation) constituted a physical disability; ${ }^{24}$ in Stephens $v$ Australian Postal Corporation, Emmett J accepted that $\mathrm{Mr}$ Stephens' lumbar spine injury constituted a physical disability; ${ }^{25}$ in Kubat $v$ Northern Health ${ }^{26}$ and Grant $v$ Victoria (The Office of Public Prosecutions) ${ }^{27}$ the Court accepted that depression constituted a mental disability; morbid obesity was found to be a disability in Findley v MSS Security Pty Ltd ${ }^{28}$ and in Pavolvich $v$ Atlantic Contractors Pty $L t d$, Jarrett FM took a slightly broader approach and accepted that a disability did not have to be permanent and could, as in the employee's case, be a temporary sickness, so the disability would only last as long as the sickness. ${ }^{29}$

$19 \quad F W A$ ss 284(1)(e), (3), 294.

$20 \quad F W A$ ss $139,153(3), 195(3)$.

21 Defined in $F W A$ s 13.

22 (2012) 225 IR 197, 233-4 [161]-[162].

23 [2012] FMCA 677, [145]-[146].

24 (2012) 224 IR 439, 447 [34]. See also Cugura v Frankston City Council [2012] FMCA 340; IEUA v AIAEI [2013] FCCA 1308.

25 [2013] FCCA 1988, [76]. Smith FM thought the same of the employee's injury in a separate claim: Stephens v Australian Postal Corporation (2011) 207 IR 405, 441 [92]. See also Shizas v Commissioner of Police (2017) 268 IR 71 ('Shizas') in which the parties agreed that ankylosing spondylitis, a form of arthritis, constituted a physical disability: at 76 [6].

26 (2015) 255 IR 70.

27 [2014] FCCA 17. See Vukovic v Myer Pty Ltd [2014] FCCA 985, [96] where anxiety amounted to a disability and Short $v$ Ambulance Victoria [2014] FCA 3, [31] where a stress injury suffered in the workplace constituted a disability. In Watson v Uniting Care [2017] FCCA 126, being distressed and visibly upset at work at times and probably being on anti-depressant or anti-anxiety medication was not found to be a disability.

28 [2017] FCCA 2898.

29 [2012] FMCA 1080, [26]. 
However, there are other cases in which the courts have not done this and have given 'disability' its ordinary meaning which has been ascertained by referring to the dictionary. In the first disability discrimination case, Hodkinson $v$ Commonwealth $^{30}$ ('Hodkinson'), Ms Hodkinson argued that her bulging discs and gynaecological problems constituted a disability, and that 'disability' should be interpreted in reference to the definition of disability in section 4 of the $D D A$. Cameron FM rejected this argument:

nothing about the way the word 'disability' is used in s 351(1) suggests that it should be understood other than according to its ordinary meaning or that it should have the extended meaning which it is given in the Disability Discrimination Act. To the extent that the Disability Discrimination Act defines 'disability' in terms consonant with the ordinary meaning of that word, it can assist in its interpretation where it appears in s 351(1). However, it is by reference to that ordinary meaning that it should be understood. In that regard, the Macquarie Dictionary $\left(5^{\text {th }}\right.$ ed) relevantly defines 'disability' as:

1. lack of competent power, strength, or physical or mental ability; incapacity.

2. a particular physical or mental weakness or incapacity.

Further, the Shorter Oxford English Dictionary $\left(6^{\text {th }}\right.$ ed) relevantly defines 'disability' as:

3. An instance of lacking ability; now spec a physical or mental condition (usu permanent) that limits a person's movements, activities, or senses. ${ }^{31}$

Cameron FM said that 'disability' means 'a particular physical or mental weakness or incapacity and ... [includes] a condition which limits a person's movements, activities or senses, ${ }^{32}$ Cameron FM found that Ms Hodkinson's bulging discs met this definition but she could not show that her gynaecological problems constituted a disability. The respondent was able to establish that it dismissed Ms Hodkinson based on her poor performance, not because of her absence from work or the reasons for the absence, namely her conditions, and so Ms Hodkinson's claim failed. ${ }^{33}$

In Stephens v Australian Postal Corporation ('Stephens'), Smith FM agreed that 'disability' should be given its ordinary meaning in the absence of a statutory test but said its meaning should be considered in the context of the objects of the provision:

The section operates in a real world, where an employer might otherwise be tempted to take adverse action by reason of one of these attributes, motivated by a variety of considerations including irrational prejudices or a rational belief that

30 (2011) 207 IR 129.

31 Ibid 165-6 [145]. By contrast in Zahra v Pharmacy Management Avoca Beach Pty Ltd, Street J applied the definition of disability from the $D D A$ and found that neither Ms Zahra's varicose veins or the period of recovery after surgery for her veins constituted a disability under the $D D A$ : [2015] FCCA 1511, [9]. See also Scullin v Coffey Projects (Australia) Pty Ltd in which Mr Scullin, relying on Hodkinson, argued that the definition of 'family responsibilities' in the Sex Discrimination Act 1984 (Cth) was relevant to interpreting its meaning in s 351, which Turner J accepted: [2015] FCCA 1514, [7]. 
the employer's business would benefit materially by removing a person with that attribute from its workforce. ${ }^{34}$

In contrast to Hodkinson, Smith FM found that Mr Stephens' lumbar spine injury and the resulting functional incapacity did constitute a disability.

\section{B Characteristics or Manifestations of the Disability}

As the discussion above shows, where the courts have had to interpret the meaning of 'disability' in section 351, they have taken a very narrow approach, including by applying incorrect definitions from elsewhere in the Act. The interpretation of disability has also been problematic when the courts have had to determine how far the definition extends - does 'disability' include temporary ailments or only permanent ones? A related question is whether 'disability' includes the disability itself or extends to the characteristics or manifestations of the disability?

Most anti-discrimination laws contain what is usually referred to as a 'characteristics extension' which broadens the definition of disability. ${ }^{35}$ These provisions state that the attribute itself includes its characteristics or manifestations and it is unlawful to discriminate on the basis of them, as well as the attribute. For example, section 4 of the DDA states: 'To avoid doubt, a disability that is otherwise covered by this definition includes behaviour that is a symptom or manifestation of the disability.'

This text was added to the definition of 'disability' in section 4 of the $D D A^{36}$ following the High Court's 'highly disruptive' decision ${ }^{37}$ in Purvis v New South Wales (Department of Education and Training) ('Purvis'). ${ }^{38}$ The child complainant in Purvis suffered from a severe brain injury which caused him to 'act out' and, following such incidents, he was expelled from school. One of the issues before the High Court was whether the manifestation of the child's disability - his aggressive outbursts - were part of his disability. In the absence of a characteristics extension, the High Court found that the outbursts were not part of his disability.

The FWA does not contain a characteristics extension. In the early case of Hodkinson, Cameron FM drew a distinction between the physical or mental limitations of a disability and the practical consequences of the limitation, such as absence from work, and said an allegation based on the latter fails to establish an element under section $351 .{ }^{39}$ However, as the next section shows, in the cases

(2011) 207 IR 405, 440 [86].

DDA s 4 (definition of 'Disability'); Discrimination Act 1991 (ACT) s 7(2); Anti-Discrimination Act 1977 (NSW) s 49B(2), (3); Anti-Discrimination Act (NT) s 20(2)(b), (c); Anti-Discrimination Act 1991 (Q1d) s 8(b), (c); Anti-Discrimination Act 1998 (Tas) ss 14(2), 15(1)(b); Equal Opportunity Act 2010 (Vic) s 7(2); Equal Opportunity Act 1984 (WA) s 66A(1)(b), (c).

Disability Discrimination and Other Human Rights Legislation Amendment Act 2009 (Cth) sch 2. Rees, Rice and Allen, above n 4, 350. On the problems with Purvis see also Belinda Smith, 'From Wardley to Purvis - How Far Has Australian Anti-Discrimination Law Come in 30 Years?' (2008) 21 Australian Journal of Labour Law 3; Margaret Thornton, 'Disabling Discrimination Legislation: The High Court and Judicial Activism’ (2009) 15(1) Australian Journal of Human Rights 1. (2003) 217 CLR 92.

Hodkinson (2011) 207 IR 129, 166 [146], [148]. 
that followed Hodkinson, the courts have found that disability extends to its manifestations.

In Stephens, Smith FM did not agree that disability should be limited in the way that Cameron FM proposed in Hodkinson. Smith FM found that:

Some of the inherent consequences of the underlying condition on the personal capacities of the disabled person, including some of the inherent consequences of the medical conditions bearing on the employee's presentation as a person and his or her work performance must be intended to be part of the employee's 'disability'. ${ }^{40}$

His Honour drew attention to one of the exceptions to section 351(1) which is found in sub-section (2)(b). It says that sub-section (1) does not apply to actions taken 'because of the inherent requirements of the particular position concerned'. Smith FM said that section 351(2)(b) shows that the legislature did not intend for an employer to accommodate all of the manifestations and effects of an employee's disability, only those which are not incompatible with performing the requirements of the job. ${ }^{41}$ Smith FM concluded that 'disability' encompasses:

the medical or scientific diagnosis of an underlying condition capable of resulting in 'disability', and also its inherent and perceived functional impairments or consequences in relation to presentation or work in a workplace, which are the manifestation of the underlying condition. ${ }^{42}$

Perry $\mathrm{J}$ agreed with this approach on appeal in RailPro Services Pty Ltd $v$ Flavel, stating that ' $[\mathrm{u}]$ nless the term included symptoms or manifestations of the disability, the Act may well fail to achieve its object' ${ }^{43}$ However, her Honour pointed out that the court needs to closely consider the reasons why the employer took the adverse action where it is not clear that the manifestation is indeed a manifestation of a disability. ${ }^{44} \mathrm{Mr}$ Flavel suffered from post-traumatic stress disorder following a train accident. He felt violently ill when he was completing an assessment of his competence as a driver and was dismissed for refusing to finish the assessment. Perry $\mathrm{J}$ agreed that feeling violently ill was a symptom of Mr Flavel's disability but she found that the employer had rebutted the onus of proof because it had showed that the decision-makers had no knowledge of $\mathrm{Mr}$ Flavel's disability, only of its symptoms. ${ }^{45}$

Whether disability includes its manifestations was considered more recently in Shizas. ${ }^{46}$ The parties agreed that the type of arthritis the employee suffered from constituted a physical disability but disagreed about whether Mr Shizas was protected from discrimination based on the physical manifestations of his disability (the fusion of his spinal joints, resulting in limited spinal movement) or whether the manifestations or practical consequences of his disability (an increased risk of spinal injury from a minor trauma) were also protected. The Commissioner of Police claimed it had refused to employ Mr Shizas because of 
the manifestation of the disability - the 'unacceptable risk' of injury he faced in the future - rather than the disability itself. Katzmann J found that as a matter of statutory construction 'disability' must include both 'the limitations and vulnerabilities that make up that disability', ${ }^{47}$ and that it would be 'difficult, if not artificial' to draw a distinction between the disability and its manifestations. ${ }^{48}$ However, the Commissioner of Police successfully argued that Mr Shizas could not perform the inherent requirements of the position and so his claim failed. ${ }^{49}$

In sum, then, while courts were initially quite restrictive in how they interpreted disability under the $F W A$, more recently they have expanded their approach to include the manifestations of the disability in the definition. This is a positive development and brings the FWA into line with the $D D A$. It is also clear from the case law that the comprehensive definition of disability contained in section 4 of the $D D A$ has not influenced the court's interpretation of disability. Part $\mathrm{V}$ returns to the problem of not having a definition in the $F W A$ and recommends incorporating the $D D A$ 's definition of disability into the Act. One advantage of having such a definition is that the employee would not have to mount a complex argument based on the case law discussed above that their ailment constituted a disability; they could simply point to the definition in the Act.

\section{DISCRIMINATION AS A FORM OF ADVERSE ACTION}

The types of behaviour that constitute adverse action are defined in section 342 and include performing the action and threatening or organising the action. ${ }^{50}$ Section 342 states that an employer takes adverse action against an employee if the employer:

(a) dismisses the employee; or

(b) injures the employee in his or her employment; or

(c) alters the position of the employee to the employee's prejudice; or

(d) discriminates between the employee and other employees of the employer.

A prospective employer takes adverse action against a prospective employee if the prospective employer:

(a) refuses to employ the prospective employee; or

(b) discriminates against the prospective employee in the terms or conditions on which the prospective employer offers to employ the prospective employee.

$47 \quad$ Ibid 96-7 [125].

48 Ibid 96 [121].

49 Unlike s $21 \mathrm{~A}$ of the $D D A$, the Commissioner was not required to make reasonable adjustments for $\mathrm{Mr}$ Shizas before assessing whether he could perform the inherent requirements. Part $\mathrm{V}$ below suggests that this requirement should be incorporated into the $F W A$. 
By itself, adverse action is not unlawful. What makes it unlawful (in the context of section 351) is if it is taken because of a protected attribute that the employee possesses, including their physical or mental disability. ${ }^{51}$

Dismissal because of a protected attribute has been prohibited in industrial relations legislation since $1993 .^{52}$ Moreover, other parts of the FWA deal with dismissal, ${ }^{53}$ so it has not been a problematic form of adverse action to apply. ${ }^{54}$ Injuring an employee in his or her employment and altering the employee's position to their prejudice are longstanding features of industrial victimisation (or anti-union) provisions ${ }^{55}$ and courts have drawn upon industrial victimisation case law in section 351 claims. $^{56}$ 'Discrimination', in this context, was introduced by the $F W A$.

The word 'discrimination' appears three times in part 3-1 of the $F W A$ - as the heading to section 351 and as two of the forms of adverse action - 'discriminate between' and 'discriminate against'. 'Discrimination' is not defined on any of the occasions in which it appears in the $F W A .^{57}$ The term's appearance in both section 351 and section 342 has caused confusion. In Sayed v Construction, Forestry, Mining and Energy Union ('Sayed'), Mortimer J noted that there is 'some circularity' in the Act in that discrimination is the taking of adverse action, and discrimination is one of the ways in which adverse action can be taken. ${ }^{58}$

Upon the enactment of the $F W A$, Rice and Roles commented that if 'discriminates' was given its ordinary meaning, then the use of the word 'between' might lead to some odd results because it would mean that simply treating an employee differently from others would be adverse action, even if the

51 The FWA prohibits adverse action in two other contexts: s 340 prohibits adverse action because the employee has a workplace right or exercises one; 346 prohibits adverse action because of an employee's membership of an industrial association or because they engage in industrial activities.

52 The Industrial Relations Reform Act 1993 (Cth) introduced a new div 3 pt VIA into what was then Industrial Relations Act 1988 (Cth) to give effect to Australia's obligations under various conventions and recommendations of the International Labor Organization. Section 170DF(1)(f) prohibited an employer from terminating employment on the basis of an employee's race, colour, sex, sexual preference, age, physical or mental disability, marital status, family responsibilities, pregnancy, religion, political opinion, national extraction or social origin. The equivalent provision was found in $170 \mathrm{CK}(2)(\mathrm{f})$ of the Workplace Relations Act 1996 (Cth), which became s 659(2)(f) following the Work Choices amendments. It is now found in s 772 of the $F W A$.

53 Part 3-2 of the Act prohibits unfair dismissal and 'dismissed' in this context is defined in s 386.

54 What is usually in dispute is whether the employee was dismissed because of a prohibited reason. See Hodkinson (2011) 207 IR 129; Flavel v Railpro Services Pty Ltd [2013] FCCA 1189.

55 'Injury' to employment was found in s 9 of the Commonwealth Conciliation and Arbitration Act 1909 (Cth). 'Injure an employee' and 'alter the position of an employee' appear in the FWA's predecessor: see Workplace Relations Act 1996 (Cth) s 792.

56 Patrick Stevedores Operations No 2 Pty Ltd v Maritime Union of Australia [No 3] (1998) 195 CLR 1 was applied by Cameron FM in Hodkinson (2011) 207 IR 129, 169 [163] and by Burnett J in Aitken v Virgin Blue Airlines (2013) 277 FLR 156, 173 [66].

57 In addition to ss 351 and 342, 'discriminate' is also used in ss 3(e), 153 and 195 but it is not defined in these contexts either. As Chapman notes, 'discrimination' has not been defined in federal industrial relations legislation since it first appeared over 30 years ago: Anna Chapman, 'Reasonable Accommodation, Adverse Action and the Case of Deborah Schou' (2012) 33 Adelaide Law Review 39, 69. 
difference was favourable. ${ }^{59}$ As discussed below, some judges have taken that view. Rice and Roles contend, though, that the word 'against' and the use of it again in section 351 indicates that 'discriminate' is to have a pejorative meaning which, they write, 'seems to be treatment that adversely affects an employee relative to another employee, very like the concept of direct discrimination in anti-discrimination law, ${ }^{60}$ Courts have made few comments about the use of 'between' and 'against'. In Construction, Forestry, Mining and Energy Union v Corinthian Industries (Australia) Pty Ltd, Pagone J said that the question of whether there has been 'discrimination between' is a different enquiry from whether there has been 'discrimination against' in that the former is a question of fact and the focus is on whether there was a difference in treatment and whether that difference was discriminatory. ${ }^{61}$ Therefore, this type of enquiry will usually require a comparator to consider the treatment against and determine whether there was a difference in treatment. ${ }^{62}$ However, in Construction, Forestry, Mining and Energy Union v Pilbara Iron Company (Services) Pty Ltd [No 3], Katzmann J concluded that there was no material difference between the two. ${ }^{63}$

Part III considers how 'discriminate' has been interpreted in the context of section $342 .{ }^{64}$ It examines cases in which the employee has alleged that the form of adverse action they were subjected to was discrimination, some of which are section 351 cases, some of which are section 340 Workplace Rights or section 346 Industrial Activities cases. Of this group of cases, only one was brought by a prospective employee, but in that case the employer admitted that it discriminated against the prospective employee.$^{65}$ For this reason, only cases in which an employer allegedly discriminated between an employee and other employees (section 342 item 1(d)) are considered. The cases reveal that discrimination as a form of adverse action has five characteristics. First, discrimination is not defined by reference to federal anti-discrimination laws. Second, discrimination is to be given its ordinary meaning. Third, different treatment constitutes discrimination. Fourth, discrimination means less favourable treatment. Fifth, discrimination might include indirect discrimination. Each is examined in turn.

\section{A Discrimination Is Not Defined in Reference to Anti-Discrimination Laws}

The courts have consistently said that discrimination in the FWA is not defined in reference to federal anti-discrimination laws. In Hodkinson, the

59

60

61

62

63

64

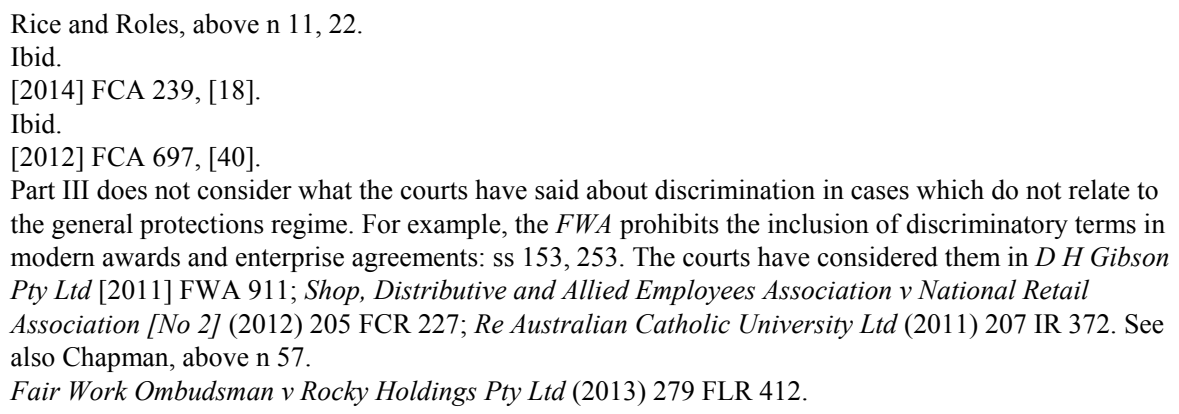
the general protections regime. For example, the $F W A$ prohibits the inclusion of discriminatory terms in modern awards and enterprise agreements: ss 153, 253. The courts have considered them in D H Gibson Pty Ltd [2011] FWA 911; Shop, Distributive and Allied Employees Association v National Retail Association [No 2] (2012) 205 FCR 227; Re Australian Catholic University Ltd (2011) 207 IR 372. See also Chapman, above n 57.

Fair Work Ombudsman v Rocky Holdings Pty Ltd (2013) 279 FLR 412. 
employee argued that the meaning of discrimination should be informed by the definitions of direct and indirect discrimination in the $D D A$. Cameron FM said that there was no relationship between the two Acts and that conduct which breaches the $D D A$ does not breach the FWA simply by reason of the contravention. ${ }^{66}$ In subsequent cases the courts have reiterated that discrimination is not determined by the definitions contained in anti-discrimination laws. ${ }^{67}$ Yet some judges have imported concepts from anti-discrimination law into their understanding of discrimination as adverse action, as the discussion below of less favourable treatment and indirect discrimination shows.

\section{B Discrimination Has Its Ordinary Meaning}

From their earliest decisions, the courts have made it clear that discrimination has its ordinary meaning. In the absence of a legislative definition they have used the dictionary. In Hodkinson Cameron FM applied the following definitions of discrimination:

The Macquarie Dictionary $\left(5^{\text {th }}\right.$ ed) relevantly defines 'discriminate' in the following terms:

1. to make a distinction, as in favour of or against a person or thing. The Shorter Oxford English Dictionary ( $6^{\text {th }}$ ed) relevantly defines 'discriminate' as:

4. Make a distinction in the treatment of different categories of people or things, esp unjustly or prejudicially against people on grounds or race, colour, sex, social status, age, etc.

The element of intent is central to these definitions. To discriminate requires a conscious decision to make a distinction, in this case between people. ${ }^{68}$

In Construction, Forestry, Mining \& Energy Union $v$ Rio Tinto Coal Australia Pty Ltd, Flick J said the meaning of discrimination in section 351 is influenced by the other instances in which 'discriminate' appears in the FWA. ${ }^{69}$ However, his Honour still gave it a narrow meaning:

The terms of s 342(1) do not suggest that the term 'discriminate' should be given anything other than in its normal meaning. Other provisions within the Fair Work Act also support the conclusion that the term 'discriminate' should be given its

66 (2011) 207 IR 129, 164-5. See also Vukovic v Myer Pty Ltd [2014] FCCA 985, [106]. In Flavel v Railpro Services Pty Ltd, Simpson J found that the employer's termination of Mr Flavel was because of his physical and mental disability and that because it was unlawful under s 15 of the $D D A$, it breached s 351 of the FWA: [2013] FCCA 1189, [88]. This was overturned on appeal: RailPro Services Pty Ltd v Flavel (2015) 242 FCR 424.

67 See Wilkie v National Storage Operations Pty Ltd [2013] FCCA 1056, [49] ('Wilkie'); Heathcote v University of Sydney [2014] FCCA 613, [107]; Sagona v R \& C Piccoli Investments Pty Ltd [2014] FCCA 875, [230] ('Sagona').

68 Hodkinson (2011) 207 IR 129, 172 [176] (emphasis in original). Information provided about s 351 in the Fair Work Commission's guide for parties to the general protections also opens with a definition of discrimination taken from Butterworths Australian Legal Dictionary: Fair Work Commission, 'General Protections Benchbook' (2 July 2018) 100.

69 (2014) 232 FCR 560. Namely ss 153,195 and 354. The first two provisions prohibit industrial instruments from including provisions which discriminate because of the attributes listed in s 351 and the final provision prohibits discrimination on the basis of whether or not an employee or prospective employee is covered by an industrial instrument or the National Employment Standards in pt 2-2 of the FWA. 
normal and ordinary meaning. And that meaning has a width of application. For the purposes of s 342(1), Item 1(d), the term 'discriminate' simply means to treat employees differently. ${ }^{70}$

Although the courts have referred to dictionary definitions in other decisions, ${ }^{71}$ in Klein $v$ Metropolitan Fire and Emergency Services Board ('Klein'), Gordon J said that there is limited value in referring to the ordinary dictionary meaning of discrimination. Her Honour said that 'discrimination' is to be construed in the context of the FWA and in a manner consistent with the policy and purpose of the Act. ${ }^{72}$

\section{Different Treatment Constitutes Discrimination}

Like Flick J in Construction, Forestry, Mining \& Energy Union v Rio Tinto Coal Australia Pty Ltd $^{73}$ other judges have said that different treatment is enough to constitute discrimination. In Construction, Forestry, Mining and Energy Union $v$ Corinthian Industries (Australia) Pty ttd $^{74}$ the respondent gave those employees who worked during a period of industrial action a $\$ 300$ gift voucher which the applicant union argued was discrimination on the basis of exercising a workplace right (namely taking industrial action), which is prohibited by section 340 of the FWA. Pagone $\mathrm{J}$ said that the meaning of discrimination in section 342 'is directed towards different treatment in comparable circumstances and not different treatment for different circumstances' ${ }^{75}$ His Honour went on to say that discrimination does not require a finding that any difference in treatment adversely affected the interests of the employee, only that the difference was in comparable circumstances. ${ }^{76}$ His Honour found that in deciding to only give the gift vouchers to certain employees, the employer was not using a criterion that treated all employees in the same position differently. The employees who received a gift voucher were in a different position to the other employees because they supported the employer's interests by working during a period of industrial action, and as the circumstances were different, the employer was entitled to treat them differently. ${ }^{77}$

In Sayed, Mortimer J said 'the conduct which is to be examined is the way in which the employer targets the particular employee. Is the employee treated differently from other employees?', and that the inquiry the court engages in is to 'look only for differential treatment'. ${ }^{78}$ In that case, her Honour found that when the applicant was directed to attend a meeting in Sydney after he had been

70 Construction, Forestry, Mining \& Energy Union v Rio Tinto Coal Australia Pty Ltd (2014) 232 FCR 560, $575[58]$.

71 See, eg, Ramos v Good Samaritan Industries [No 2] [2011] FMCA 341, [59]-[60]; Construction, Forestry, Mining and Energy Union v Pilbara Iron Co (Service) Pty Ltd [No 3] [2012] FCA 697, [40].

72 (2012) 208 FCR 178, 201-2 [89].

73 (2014) 232 FCR 560

74 [2014] FCA 239.

75 Ibid [18].

76 Ibid.

77 Ibid.

78 (2015) 327 ALR 460, 492 [160]. 
criticising officials of another union and their delegates, he was treated the same way as a hypothetical employee who had behaved in the same way would have been. ${ }^{79}$ In Construction, Forestry, Mining and Energy Union v Pilbara Iron Company (Service) Pty Ltd [No 3], Katzmann J said that discrimination 'requires that one employee is treated differently from others in the same or comparable circumstances' 80

\section{Discrimination Means Less Favourable Treatment}

Despite various judges deciding not to use definitions from antidiscrimination law to give meaning to disability and discrimination, some concepts and cases from that body of law have found their way into FWA decisions. Anti-discrimination laws prohibit two forms of discrimination - direct (which is concerned with treatment) and indirect (which is concerned with effect, and is discussed below). Direct discrimination occurs when an employer treats an employee with a disability less favourably than an employee without a disability in similar circumstances. ${ }^{81}$ In Purvis, the High Court said the appropriate comparator is one who engages in the same behavior as the complainant but who does not possess the attribute in question. ${ }^{82}$ In Board of Bendigo Regional Institute of Technical and Further Education v Barclay ('Barclay'), ${ }^{83}$ French CJ and Crennan $\mathrm{J}$ said that to discharge its burden, it would be 'appropriate for a decision-maker to give positive evidence comparing the position of the employee affected by the adverse action with that of an employee who has no union involvement ${ }^{84}$ that is, one without the protected attribute. ${ }^{85}$ This follows the approach in Purvis. ${ }^{86}$ Courts have also applied the comparator test in section 351 cases. In Evangeline v Department of Human Services, Coker J said that to argue that her employer took adverse action because of a proscribed attribute, Ms Evangeline was required to show that the employer would have acted in a different manner if she was not a woman or did not suffer from a physical or mental disability. ${ }^{87}$ In Short $v$ Ambulance Victoria, although Marshall ACJ did not articulate the test as such, his Honour applied a comparator test in effect when he said that withdrawing the offer of an interview from the employee could not constitute discrimination because no other employees were interviewed. ${ }^{88}$

Quite unlike anti-discrimination law, in some $F W A$ cases the courts have required the employee to establish that the employer intended to or deliberately

\footnotetext{
79 Ibid 492-3 [162].

80 [2012] FCA 697, [43].

$81 D D A$ s $5(1)$.

82 (2003) 217 CLR 92, 101 (Gleeson CJ), 161-2 (Gummow, Hayne and Heydon JJ).

83 (2012) 248 CLR 500.

84 Ibid 524.

85 See also Stephens (2011) 207 IR 405, 439 [83]-[84].

86 In the Full Federal Court decision in Barclay, Gray and Bromberg JJ also said that a comparator test of the kind used in Purvis was appropriate if the form of adverse action was discrimination: Barclay $v$ Board of Bendigo Regional Institute of Technical and Further Education (2011) 203 IR 312, 323-4.

87 [2013] FCCA 807, [101].

88 [2014] FCA 3, [24].
} 
treated them less favourably. ${ }^{89}$ In Hodkinson, Cameron FM said discrimination 'involves an employer deliberately treating an employee, or a group of employees, less favourably than others of its employees'. ${ }^{90}$ His Honour emphasised that ' $[t]$ he element of intent is central to these definitions [of discrimination]. To discriminate requires a conscious decision to make a distinction, in this case between people'. ${ }^{91}$ Applying this in Ramos $v$ Good Samaritan Industries [No 2], Driver FM said that as Mr Ramos' complaint was one of direct discrimination, it was necessary for him 'to prove that [the employer] deliberately treated him less favourably than its other employees'. ${ }^{92}$ In Aitken $v$ Virgin Blue Airlines, Burnett $\mathrm{J}$ said that discrimination 'requires a comparison of the treatment of the employee as between other employees, which is consistent with the differential treatment encapsulated by direct discrimination' and, his Honour added, the employee must establish that their position was 'affected to their detriment in a real and substantial manner' as a result of an intentional act. ${ }^{93}$

\section{E Discrimination Might Include Indirect Discrimination}

In anti-discrimination law, indirect discrimination is typically defined as the imposition of a requirement, condition or practice which is neutral on its face but has a disadvantageous effect on an employee because of their disability, and which is not reasonable. ${ }^{94}$ The $F W A$ does not appear to prohibit indirect discrimination..$^{95}$ In the way it is worded, section 351 targets direct discrimination - adverse action because of an attribute. The absence of a distinction between direct and indirect discrimination was one of the reasons Smith was optimistic about section $351,{ }^{96}$ but the Act's failure to state whether or not indirect discrimination is prohibited may in fact be problematic.

The Federal Court has found that discrimination includes indirect discrimination. ${ }^{97}$ In Klein, Gordon $\mathrm{J}$ considered the historical reasons legislatures have prohibited indirect discrimination and found that discrimination in the FWA should be construed to include indirect discrimination:

The High Court confirmed early on that it is not necessary to prove intent or motive when establishing discrimination in anti-discrimination law: Waters v Public Transport Corporation (1991) 173 CLR 349, 359 (Mason CJ and Gaudron J), 382 (Deane J agreeing) ('Waters'). (2011) 207 IR 129, 173 [178] (emphasis added).

Ibid [176].

[2011] FMCA 341, [62] (emphasis added).

(2013) 277 FLR 156, 175 [81]-[82].

$D D A$ s 6.

The Fair Work Ombudsman has consistently held the view that s 351 prohibits indirect discrimination: Fair Work Ombudsman, FWO Discrimination Policy, Guidance Note No 6, 21 December 2012, 5.4. Chapman writes that discrimination has been interpreted to include indirect discrimination since it first appeared in federal industrial relations legislation: Chapman, above n 57, 69, n 162. See also Rice and Roles on the indicators that $\mathrm{s} 351$ does prohibit indirect discrimination: above $\mathrm{n} 11,25 \mathrm{ff}$.

Smith, 'Fair and Equal', above n 9.

See, eg, Klein (2012) 208 FCR 178, 206 [102] (Gordon J). See also Wilkie [2013] FCCA 1056, [49]

(Whelan J); Wolfe v Australia and New Zealand Banking Group Ltd [2013] FMCA 65, [83] (Whelan FM); Sayed (2015) 327 ALR 460, 490-1 [155] (Mortimer J). 
It is now recognised that an employer's particular reason for choosing a 'facially neutral' criterion may in fact be its adverse impact on a protected group. In another words, although the employer chose a seemingly innocent or innocuous criterion, the employer did so for a prohibited reason or basis. There is nothing in the language of Pt 3-1 of the FW Act that would support limiting 'discrimination' for the purposes of Item 1(d) of the definition of 'adverse action' in s 342 so as to exclude 'facially neutral' or indirect discrimination of that kind. ${ }^{98}$

In subsequent cases the courts accepted that following Klein, section 342 includes indirect discrimination. ${ }^{99}$ For example, in Keys $v$ Sydney Night Patrol and Inquiry Co Pty Ltd, Driver $\mathrm{J}$ said that there was no indirect age discrimination because there was 'no evidence that persons of Mr Keys' age were less able to pass the [fitness] test than younger persons' ${ }^{100}$ In effect, Driver $\mathrm{J}$ applied the test for indirect discrimination - whether the fitness test had or was likely to have a disadvantageous effect on employees who are the same age as Mr Keys ${ }^{101}$ - though his Honour did not consider whether it was reasonable for the employer to use the fitness test. In Sayed, Mortimer J said that it would be difficult to incorporate the concept of 'reasonableness', which is fundamental to indirect discrimination, into the text of sections 351 and $342 .{ }^{102}$ However, that would mean Parliament meant only to prohibit the 'most obvious and direct kinds' of discrimination when it enacted section 351, which would be a significant omission. ${ }^{103}$ Her Honour was not required to make a decision on this point and the issue has not been considered since. Including a clear prohibition of indirect discrimination in the $F W A$ is one of the suggestions presented in Part V as a way of improving the Act's ability to tackle disability discrimination.

The examination of the cases in which the court has interpreted 'discrimination' in the FWA shows that the jurisprudence is developing quite differently from traditional anti-discrimination law, such as by requiring intent or motivation to be proved. Furthermore, the jurisprudence has not developed in the way that was envisaged by commentators when the Act came into force. ${ }^{104}$ Before considering what changes could be made to strengthen both 'disability' and 'discrimination', Part IV examines how section 351 is enforced and how it differs from anti-discrimination law.

\section{ENFORCING SECTION 351}

Section 351 claims can be brought by the individual employee or prospective employee, an industrial association and the Fair Work Ombudsman ('FWO'). ${ }^{105}$

98 (2012) 208 FCR 178, 206 [102].

99 Whelan FM said that, following Klein, discrimination may be direct or indirect: Wolfe v Australia and

New Zealand Banking Group Ltd [2013] FMCA 65, [83]; Wilkie [2013] FCCA 1056, [49]; Sagona

[2014] FCCA 875, [230].

100 [2015] FCCA 776, [22].

101 See Age Discrimination Act 2004 (Cth) s 15.

102 (2015) 327 ALR 460, 490-1 [155].

103 Ibid.

104 See the comments by Smith, above n 9, and Rice and Roles, above $\mathrm{n} 11$.

105 FWA s 539. 
How a claim is resolved depends upon whether the employee was dismissed. If so, they are required to lodge a claim at the Fair Work Commission within 21 days of the dismissal taking effect. ${ }^{106}$ The Commission will then convene a private conference and attempt to resolve the claim through mediation or conciliation, or by making a recommendation or by expressing an opinion. ${ }^{107}$ Submissions to the AHRC's inquiry into discrimination experienced by employees with a disability raised concerns about the length of this period. Victoria Legal Aid, for example, had found that for some clients, a dismissal 'may have been related to an illness, or it may exacerbate an illness', therefore making them too unwell to pursue their claim for some time, and resulting in it being too late to use the $F W A .{ }^{108}$ Employees who fall outside the 21-day limit will have to use anti-discrimination laws.

If the parties cannot reach a resolution, the Fair Work Commission will issue a certificate stating that all reasonable attempts to resolve the dispute have been unsuccessful. The employee then has 14 days in which to lodge an application in the Federal Court or the Federal Circuit Court. ${ }^{109}$ If the employee was not dismissed, they can elect to lodge the claim at the Fair Work Commission, which will conduct a private conference if both parties agree to participate. ${ }^{110}$ The employee is prevented from lodging a claim under the $F W A$ and a federal, state or territory anti-discrimination law simultaneously. ${ }^{111}$ The Federal Court and Federal Circuit Court can make any order they think is appropriate if they find that section 351 has been breached including ordering compensation and reinstatement. They can also order an injunction to stop or remedy the contravention. ${ }^{12}$ To date, compensation for economic and non-economic loss has been the most common remedy ordered in a disability discrimination claim. ${ }^{113}$

Apart from the 21-day time limit, the enforcement process described so far does not vary much from how anti-discrimination laws are enforced. ${ }^{114}$ The $F W A$ is different in three significant ways - the court can impose pecuniary penalties for breaching section 351; an independent regulator has the power to enforce section 351 and seek the imposition of penalties; and the FWA contains a shifting onus of proof. None of these mechanisms feature in anti-discrimination law and

$106 F W A$ ss $365,366$.

107 FWA s 595(2).

108 Willing to Work, above n 1, 330.

$109 F W A$ ss $369,370$.

$110 F W A$ ss $372-4$.

111 FWA ss 725, 727-32, 734.

$112 F W A$ s 545.

113 Compensation was ordered in two cases (Heriot v Sayfa Systems Pty Ltd (No 2) [2014] FCCA 1627; Penglase v Allied Express Transport Pty Ltd [2015] FCCA 804) and agreed to by the parties prior to hearing in two others (Fair Work Ombudsman v Drivecam Pty Ltd (2011) 208 IR 79; Fair Work Ombudsman v Rocky Holdings Pty Ltd [2013] FCCA 1549). In the fifth case, the claim for compensation was abandoned before hearing and only a civil penalty was sought (Pavolvich v Atlantic Contractors Pty Ltd [2012] FMCA 1080).

114 The main difference is that conciliation must be attempted, regardless of the nature of the claim, before the employee can litigate in all jurisdictions except Victoria. See also Rees, Rice and Allen, above $\mathrm{n} 4$, ch 15 . 
they give the $F W A$ great potential to address workplace discrimination. This potential - and suggestions for strengthening the Act - are explored in Part V.

Section 351 is a civil penalty provision, so the court can impose a pecuniary penalty of up to 60 penalty units per breach for an individual $(\$ 12600)$ and up to five times that amount for a body corporate. ${ }^{115}$ Penalties can be sought by the affected employee, an industrial association and the FWO. ${ }^{116}$ For example in Pavolvich and Atlantic Contractors Pty Ltd the employer was required to pay a penalty of 50 per cent of the maximum for what was found to be significant conduct where the employer acted in disregard of its obligations under the $F W A$ and without any form of contrition. ${ }^{117}$

The FWO can enforce section 351. It does so by receiving and investigating complaints about breaches of the Act and, if necessary, litigating claims on behalf of an employee or prospective employee. This makes the FWA quite different from the $D D A$, which can only be enforced by an individual or a representative on their behalf. ${ }^{118}$ During an investigation, a Fair Work Inspector may enter a workplace and obtain evidence by interviewing the employer and witnesses. They can also require documents to be produced. ${ }^{119}$ If the FWO reasonably believes that a person has contravened section 351, it may accept enforceable undertakings in which the employer acknowledges the breach and agrees to take action to address the breach and/or not to contravene the $F W A$ in the future. ${ }^{120}$ The FWO has not accepted any in relation to discrimination claims in the past few years, but it did so when the Act first commenced. For example, in 2011-12, it entered into three enforceable undertakings in discrimination claims, one of which related to disability discrimination. In that instance, a job offer as a business development manager was withdrawn when a prospective employee revealed a long-term shoulder injury. However, the job was not advertised as having any physical requirements, nor were they an inherent part of the position. In addition to paying the prospective employee $\$ 30 \quad 000$ compensation, the employer was required to ensure its human resource managers and recruitment staff completed anti-discrimination training, ensure compliance with the FWA in the future, review its recruitment practices particularly in relation to medical assessments, and report on its findings to the FWO. ${ }^{121}$

If a claim cannot be resolved voluntarily or through enforceable undertakings, the FWO can litigate the claim, and it can seek the imposition of civil penalties. ${ }^{122}$ Initially the FWO was quite active in ensuring compliance with section 351 . In saying that, it has not pursued that many discrimination claims. It

$115 F W A$ ss 539 item 11, 546. A 'penalty unit' has the meaning afforded to it by s 4AA of the Crimes Act 1914 (Cth). It is currently set at $\$ 210$.

$116 \quad F W A$ s 539.

117 [2012] FMCA 1080.

118 Australian Human Rights Commission Act 1986 (Cth) s 46P(2).

119 FWA ss 708, 709, 712, 714.

120 FWA s 715.

121 Fair Work Ombudsman, 'Enforceable Undertaking Given by James Hardie Australia Pty Ltd to the Commonwealth of Australia' (17 May 2012) < https://www.fairwork.gov.au/about-us/our-role/enforcingthe-legislation/enforceable-undertakings/2011-2012-enforceable-undertakings $>$. 
litigated three discrimination claims in 2012, two in 2013 but only one in 2011 and 2014, and then none until 2017. Of the cases it has litigated, two were about physical disability. ${ }^{123}$ It sought and obtained the imposition of penalties of around $\$ 4000$ in each case.

The $F W A$ contains a reverse onus of proof. Section 361 provides that once an employee or prospective employee alleges that they were subject to adverse action and establishes that they possessed one of the attributes listed in section 351 , it is presumed that the adverse action was taken because of the attribute unless the employer proves otherwise. The High Court has considered the operation of section 361 twice and it has received substantial academic attention. ${ }^{124}$ In Barclay, French CJ and Crennan J said:

The imposition of the statutory presumption in $\mathrm{s} 361$, and the correlative onus on employers, naturally and ordinarily mean that direct evidence of a decision-maker as to state of mind, intent or purpose will bear upon the question of why adverse action was taken, although the central question remains "why was the adverse action taken?'.

This question is one of fact, which must be answered in the light of all the facts established in the proceeding. ${ }^{125}$

Similarly, Gummow and Hayne JJ said 'the reasons of the decision-maker at the time the adverse action was taken [will be] the focus of the [court's] inquiry'. ${ }^{126}$ The Court held that the protected attributes must be an operative factor in why the adverse action was taken, on the balance of probabilities. ${ }^{127}$ The Court upheld this approach in Construction, Forestry, Mining and Energy Union $v$ BHP Coal Pty Ltd. ${ }^{128}$

In sum, then, the $F W A$ benefits from a relatively simple, informal and quick enforcement model under which employees bear less of the burden for enforcing their claim than they do under traditional anti-discrimination law. This is due to the shifting onus of proof and the presence of an agency with the power to pursue non-compliant employers and seek hefty penalties. The differences between the $F W A$ and anti-discrimination law are considered further in Part V, along with suggestions for improving the enforcement model to more effectively address workplace discrimination for employees with a disability.

123 Fair Work Ombudsman v Drivecam Pty Ltd (2011) 208 IR 79; Fair Work Ombudsman v Rocky Holdings Pty Ltd (2013) 279 FLR 412.

124 See, eg, Anna Chapman, Kathleen Love and Beth Gaze, 'The Reverse Onus of Proof Then and Now: The Barclay Case and the History of the Fair Work Act's Union Victimisation and Freedom of Association Provisions' (2014) 37 University of New South Wales Law Journal 471; Beth Gaze and Belinda Smith, Equality and Discrimination Law in Australia: An Introduction (Cambridge University Press, 2017), 236-41.

125 (2012) 248 CLR 500, 517 [44]-[45] (citation omitted).

126 Ibid 542 [127].

127 Ibid 523 [62] (French CJ and Crennan J).

128 (2014) 253 CLR 243 


\section{STRENGTHENING THE FAIR WORK ACT}

The FWA contains a number of features that make it an attractive option for pursuing a discrimination claim for employees with a disability, especially compared to anti-discrimination law. First, the reverse onus of proof makes the employee's burden of proof significantly lighter than it is in anti-discrimination law. Under the $F W A$ the employee need only make an allegation that they were subject to unlawful adverse action before the onus shifts to the employer to rebut the presumption by providing a lawful reason for why it took the adverse action. Conversely, in anti-discrimination law the burden of proof rests entirely on the employee except for indirect discrimination in some jurisdictions. ${ }^{129}$ Second, section 351 does not rely solely on individual enforcement; both the FWO and industrial associations can enforce it, whereas the $D D A$ (like all antidiscrimination laws) relies on the individual employee. Third, significant civil penalties can be imposed on employees and employers who breach section 351 . This is intended to provide a powerful deterrent and encourage compliance with the Act. Finally, the FWO has the power to negotiate creative ways of addressing discrimination and promoting future compliance through its investigations and by reaching enforceable undertakings. These are made public to encourage other employers to comply lest they are also investigated. However, the way in which section 351 has been interpreted is compromising the effectiveness of these positive features.

While it was initially seen as a benefit, the open-textured, simple language of section 351 has proven to be problematic because 'physical or mental disability' and 'discrimination' are not defined and both have been interpreted narrowly. The remainder of Part $\mathrm{V}$ offers suggestions for how the FWA could be strengthened to offer employees with a disability a much stronger option for pursuing a workplace discrimination claim. The suggestions relate to four aspects - defining 'physical and mental disability', defining 'discrimination', improving the enforcement of section 351, and introducing proactive measures to address workplace discrimination.

\section{A Define Physical or Mental Disability}

Gaze and Smith recently wrote that, given the decades of anti-discrimination jurisprudence, 'it would be strange for courts to completely ignore them in interpreting the attributes in $\mathrm{s} 351^{\prime}{ }^{130}$ Yet in the first case of disability discrimination Cameron FM said that disability should not have the extended meaning given to it in the $D D A .{ }^{131}$ In all except two subsequent cases, the courts have chosen not to define the attributes listed in section 351 in reference to Commonwealth anti-discrimination laws. ${ }^{132}$ The simple solution to this problem is to define 'physical or mental disability' in the Dictionary in section 12 of the

$129 D D A$ s 6(4). See below n 134.

130 Gaze and Smith, above n 124, 232.

131 Hodkinson (2011) 207 IR 129, 165-6 [145].

132 See above n 31. 
$F W A$. There would be no need to formulate a new definition; the broad definition in the $D D A$, which has received widespread support, ${ }^{133}$ could be used:

disability, in relation to a person, means:
(a) total or partial loss of the person's bodily or mental functions; or
(b) total or partial loss of a part of the body; or
(c) the presence in the body of organisms causing disease or illness; or
(d) the presence in the body of organisms capable of causing disease or illness; or
(e) the malfunction, malformation or disfigurement of a part of the person's body; or
(f) a disorder or malfunction that results in the person learning differently from a person without the disorder or malfunction; or
(g) a disorder, illness or disease that affects a person's thought processes, perception of reality, emotions or judgment or that results in disturbed behaviour; ...

Disability includes manifestations or characteristics of the disability, and ailments that exist, previously existed or may exist in the future. ${ }^{134}$ This definition encapsulates what is known as the 'social model' of disability, which describes disability in the context of how a person's disability interacts with the external world, as opposed to a medical model 'in which a diagnosis or categorisation of condition leads to particular consequences for individuals' ${ }^{135}$ As commentators have noted, a broad definition means that when pursuing a discrimination claim, an employee with a disability does not have to spend time determining whether or not they meet the definition and the court can focus on the central issues in the case. ${ }^{136}$ As the discussion of the $F W A$ case law showed, while this has been the experience of some employees, for others it has not, and the interpretation that has emerged is not broad or inclusive.

\section{B Define Discrimination}

The definition of discrimination in the $F W A$ is a simple one, drawn from ordinary language or the dictionary and it primarily encompasses direct discrimination. It is not possible to identify a single definition of discrimination

133 For example, it was used to establish coverage of Australia's National Disability Strategy: Rees, Rice and Allen, above n 4, 347. Upon the enactment of the $D D A$, Basser and Jones commented that the broad definition of disability was a 'unique and powerful feature' of the $D D A$ : Lee Ann Basser and Melinda Jones, 'The Disability Discrimination Act 1992 (Cth): A Three-Dimensional Approach to Operationalising Human Rights' (2002) 26 Melbourne University Law Review 254, 263. In its review of the $D D A$, the Productivity Commission noted that definition of disability is 'deliberately broad' and intended to cover all types of disability: Productivity Commission, 'Review of the Disability Discrimination Act 1992' (Report No 30, 30 April 2004) vol I, 46-7.

$134 D D A$ s 4(h)-(k) (definition of 'disability').

135 Australian Law Reform Commission, Equality, Capacity and Disability in Commonwealth Laws, Report No 124 (2014) 38. The Convention on the Rights of Persons with Disabilities, opened for signature 30 March 2007, 2515 UNTS 3 (entered into force 3 May 2008) ('CRPD') does not use the medical model either.

136 Basser and Jones, above n 133, 261; Productivity Commission, above n 133, 47; Willing to Work, above n $1,339$. 
from the cases to date. Discrimination means anything from 'to distinguish', 'to treat differently', or 'to treat less favourably'.

There are two problems with the courts' interpretation of discrimination. The first is that the varying definitions all equate to a very simple understanding of discrimination. Discrimination primarily appears to mean 'to treat differently', which is less than and different from 'to treat unequally'. At first it may appear that it will be easier to establish discrimination if an employee only has to show that a distinction was made between them and other employees, or that they were treated differently from other employees, before the onus shifts to the employer. It may in fact make it harder because, unlike anti-discrimination laws, the $F W A$ does not explicitly permit an employee to show how a hypothetical employee would have been treated. ${ }^{137}$ They need evidence of how an actual employee was treated and this may be difficult to obtain.

The more significant problem with the simple definition is that it does not adequately encompass what is meant by 'discrimination'. A provision prohibiting discrimination is not usually intended to target a mere difference in treatment; it is intended for instances in which the employee has suffered a detriment or loss, such as a job opportunity, promotion, salary increase or training opportunity, because of an irrelevant attribute. Anti-discrimination law calls this 'direct discrimination' and requires the employee to show that they were subject to less favourable, unfavourable or detrimental treatment. ${ }^{138}$ Regardless of the wording, the focus is on unequal treatment. Mere difference in treatment does not go to the heart of the meaning of discrimination, so allowing section 342 to continue developing in this fashion may undermine the legislature's intention and not address the problem of workplace discrimination.

Since the 1970s it has been acknowledged that defining discrimination as less favourable treatment does not capture all forms of discrimination. ${ }^{139}$ In particular it does not capture the application of a criterion which is neutral on its face but has an unequal impact on an employee because of an irrelevant attribute, such as only providing documents in printed form so employees who are visually impaired cannot access them or requiring a job applicant to hold a current driver's licence when driving is not a significant part of the job. For this reason, the $D D A$ (like the other anti-discrimination statutes) also prohibits 'indirect discrimination'. ${ }^{140}$

Although some judges have found that 'discrimination' in the $F W A$ includes indirect discrimination, it cannot be said that this is apparent from the statute. Nor is there any indication in either the Explanatory Memorandum or Second Reading speech to suggest that this was Parliament's intention, ${ }^{141}$ so a subsequent

$137 \mathrm{Cf} D D A$ s 5(1). However, at least in one case the court has relied upon a hypothetical employee. See the discussion of Sayed at above $\mathrm{n} 78$ and accompanying text.

$138 D D A$ s $5(1)$.

139 This was made clear by the US Supreme Court in its landmark decision Griggs v Duke Power Co, 401 US 424 (1971) which led to the prohibition of indirect discrimination in that country and many others. See further Rees, Rice and Allen, above n 4, $138 \mathrm{ff}$.

$140 D D A$ s 6.

141 However, it can also be said that there is no indication that Parliament intended to exclude indirect discrimination. Indeed, Rice and Roles argue that there are 'strong indications' that discrimination 
or superior court could reach a different conclusion. To avoid this, the FWA should be amended to include a prohibition of indirect discrimination which prohibits employers from requiring an employee with a disability to comply with a requirement, condition or practice which has (or is likely to have) a disadvantageous effect on them because of their disability and which is not reasonable in the circumstances. The DDA was amended in 2009 to place the burden of showing that the requirement, condition or practice was reasonable on the employer. ${ }^{142}$ The reason for this is that the employer is the party who is in the best position to explain or justify its behaviour, and so it is suggested that an indirect discrimination provision in the $F W A$ is drafted in the same way.

\section{Enforcement and the FWO}

In terms of enforcement, the value of the flexible dispute resolution processes offered by the Fair Work Commission and the advantages of the reverse onus of proof will only be realised if employees can access the Fair Work system. A 21day limit gives dismissed employees a very small window in which to ascertain that they have a claim, identify the forum for pursuing it and commence legal action, particularly for vulnerable employees. It is suggested that this should be expanded if not for section 351 claims generally, then for employees with a disability regardless of the nature of their claim.

It is worth noting that one of the FWO's functions is to litigate cases and one of the factors it takes into account when deciding to litigate is whether judicial clarification of the law is required. ${ }^{143}$ In most of the discrimination cases the FWO has litigated to date, the parties filed an agreed statement of facts, so the court was only required to determine the penalty, and there was no opportunity to interpret the law. ${ }^{144}$ Given that section 351 is a new element of the industrial relations landscape and there is much uncertainty around what it means, it seems that it would be very useful for the FWO to litigate in this area and attempt to develop the law in a clear, consistent way.

\section{Proactive Measures to Address Discrimination}

Even if discrimination was defined in the FWA and it included indirect discrimination, section 351 would continue to be a reactive way of addressing workplace discrimination, not a proactive one. That is, it would not permit an employer to do something positive for employees with a disability because, arguably, that would discriminate against employees without a disability. This may be a disincentive for employers who want to do something to benefit an employee with a disability in their workplace. By contrast, the $D D A$ permits

encompasses indirect discrimination: Rice and Roles, above n 11, 25. The FWO also holds this view: see above $\mathrm{n} 95$

$142 D D A$ s 6(4). This was inserted by the Disability Discrimination and Other Human Rights Legislation Amendment Act 2009 (Cth). The indirect discrimination provisions in the Sex Discrimination Act 1984 (Cth) and the Age Discrimination Act 2004 (Cth) are drafted in much the same way.

143 Fair Work Ombudsman, FWO Litigation Policy, Guidance Note No 1, 3 December 2013, [4.2], [9.1].

144 See, eg, Fair Work Ombudsman v Rocky Holdings Pty Ltd (2013) 279 FLR 412; Fair Work Ombudsman $v$ Tiger Telco Pty Ltd (in liq) [2012] FCA 479. 
employers to take positive action (known as special measures) to ensure that an employee with a disability has opportunities equal to employees who do not have a disability and to allow employers to take action to meet the special needs of employees with a disability. ${ }^{145} \mathrm{~A}$ simple amendment to the $F W A$ to permit special measures for these purposes would bring the Act in line with the $D D A$ and conform with Australia's obligations under the Convention on the Rights of Persons with Disabilities, which permits special measures to achieve equality for persons with disabilities. ${ }^{146}$

There is a defence available to employers who discriminate on the basis of an employee's disability if they can show that they took the adverse action because of the inherent requirements of the position concerned. ${ }^{147}$ This argument was successfully raised recently by the Commissioner of Police in Shizas; Katzmann $\mathrm{J}$ found that the decision-maker genuinely believed that Mr Shizas could not carry out the inherent requirements of the position because he thought Mr Shizas might be injured when carrying out his duties and if his condition (fusion of his spinal joints) suddenly deteriorated, this would put his partner and members of the public at risk. ${ }^{148}$ In making this assessment, the employer was not required to make reasonable adjustments for Mr Shizas before assessing whether he could perform the inherent requirements of the position, as would have been the case under the $D D A .{ }^{149}$ Perhaps the decision-maker would have reached the same conclusion, but they would have been required to turn their mind to how $\mathrm{Mr}$ Shizas' condition could be accommodated first.

Moreover, an employer is not obliged under the $F W A$ to make reasonable adjustments so that an employee with a disability can perform a job. This was confirmed by Riley J in Kubat v Northern Health. ${ }^{150}$ Her Honour said '[section 351] does not impose a positive obligation on an employer to accommodate an employee who is physically or mentally unable to do all of the elements of his or her job'. ${ }^{151}$ By contrast, the $D D A$ places an obligation on employers to reasonably accommodate an employee's disability. The failure to do so amounts to discrimination. ${ }^{152}$

One of the FWA's objects is to provide a framework for 'productive workplace relations' that promotes 'social inclusion for all Australians'. ${ }^{153}$ Unless there is an obligation on employers to make reasonable adjustments and accommodate an employee's disability (including before they assess whether or not they can perform the inherent requirements of the job), it is difficult to see how workplaces will become more inclusive, and the barriers to employment for

$145 D D A$ s 45.

146 CRPD article 5.

$147 \quad F W A$ s $351(2)(\mathrm{b})$.

148 (2017) 268 IR 71, 106 [173]-[174].

$149 D D A$ s $21 \mathrm{~A}$.

150 (2015) 255 IR 70.

151 Ibid.

152 See $D D A$ s 5(2). The $C R P D$ art 5 also requires States Parties to take steps to ensure that reasonable accommodation is provided.

153 FWA s 3. 
people with a disability that were identified in the AHRC's Willing to Work report will remain.

\section{CONCLUSION}

The interpretation of anti-discrimination law has had a troubled history in Australia. Many commentators have bemoaned the fact that a law that was initially construed broadly and beneficially is now interpreted restrictively. ${ }^{154}$ As Kirby J put it in New South Wales v Amery, '[t]he wheel has turned' ${ }^{155}$ For example, the High Court took a much more restrictive approach to the most recent disability discrimination case it heard (Purvis) than it did in the first (Waters). The Court has only heard four disability discrimination cases in total but only the complainant in the first case, Waters, itself a high watermark in the jurisprudence, succeeded. So in many ways it is admirable that drafters did not replicate this approach in the $F W A$. However, this article shows that too much has been left open and that this is limiting the Act's effectiveness at tackling the discrimination faced by employees with a disability. There is now enough case law about discrimination in the $F W A$ to identify significant problems with its interpretation and to give some thought to clarifying the meaning of discrimination and disability. Combined with the reverse onus of proof and the existence of a strong regulator, such changes may make the FWA a more attractive option for an employee with a disability who experiences workplace discrimination than traditional anti-discrimination law.

154 See generally Smith, above n 37; Gaze, above n 7; Thornton, above n 37. Kirby J was also of this opinion in one of the High Court's most recent discrimination decisions: New South Wales v Amery (2006) 230 CLR 174, 200-1.

155 (2006) 230 CLR 174, 200 [88]. 